\title{
Biological invasion of the Indo-Pacific lionfish Pterois volitans along the Atlantic coast of North America
}

\author{
Paula E. Whitfield ${ }^{1, *}$, Todd Gardner ${ }^{2}$, Stephen P. Vives ${ }^{3}$, Matthew R. Gilligan ${ }^{4}$, \\ Walter R. Courtenay Jr. ${ }^{5}$, G. Carleton Ray ${ }^{6}$, Jonathan A. Hare ${ }^{1}$ \\ ${ }^{1}$ NOAA Beaufort Laboratory, 101 Pivers Island Road, Beaufort, North Carolina 28516, USA \\ ${ }^{2}$ Biology Department, 130 Gittleson Hall, Hofstra University, Hempstead, New York 11549-1140, USA \\ ${ }^{3}$ Department of Biology, Georgia Southern University, PO Box 8042, Statesboro, Georgia 30460-8042, USA \\ ${ }^{4}$ Marine Science Programs, Savannah State University, PO Box 20467, Savannah, Georgia 31404, USA \\ ${ }^{5}$ Florida Caribbean Science Center, US Geological Survey, 7920 NW 71st Street, Gainesville, Florida 32653, USA \\ ${ }^{6}$ Department of Environmental Sciences, University of Virginia, 291 McCormick Rd, Charlottesville, Virginia 22904, USA
}

\begin{abstract}
The occurrence of lionfish Pterois volitans is reported from the western Atlantic Ocean. Adults were collected off the coasts of North Carolina, Georgia and Florida, and juveniles were collected along the shore of Long Island, New York. They have also been found around Bermuda. Lionfish are indigenous to tropical waters of the western Pacific and their occurrence along the east coast of the United States represents a human-induced introduction. Distribution of adults suggests lionfish are surviving in the western Atlantic and capture of juveniles provides putative evidence of reproduction. The most likely pathway of introduction is aquarium releases, but introduction via ballast water cannot be ruled out. The ecosystem of the southeastern United States continental shelf is already undergoing change: reef fish communities are becoming more tropical and many fish species are overfished. These ongoing changes, along with limited information regarding the biology of $P$. volitans, make predictions of long-term effects of the introduction difficult. This discovery represents the first, apparently successful introduction, of a marine fish from the western Pacific to Atlantic coastal waters of the United States.
\end{abstract}

KEY WORDS: Biological invasions · Nonindigenous species · Marine fish $\cdot$ Scorpaenidae $\cdot$ Marine introductions $\cdot$ Lionfish $\cdot$ Pterois volitans $\cdot$ Invasive species $\cdot$ Pteroinae

Resale or republication not permitted without written consent of the publisher

\section{INTRODUCTION}

Biological invasions consist of the arrival, survival, successful reproduction and dispersal of a species in an ecosystem where the species did not exist previously (Carlton 1989). Invasions can result from natural range extensions or from human-induced introductions (Carlton 1989). Over the past 2 decades, introductions of nonindigenous marine species have occurred more frequently, raising concerns over their impacts on

\footnotetext{
*E-mail: paula.whitfield@noaa.gov
}

marine ecosystems (Cohen \& Carlton 1998, Ruiz et al. 2000). A number of studies have documented pathways of marine introductions (i.e. arrival) and outlined factors and mechanisms that lead to successful invasions (i.e. dispersal; Carlton 1985, Carlton \& Geller 1993, Ruiz et al. 1997, Wonham et al. 2000, 2001).

There are striking differences in marine fish introductions compared to introductions of other marine species (Baltz 1991). First, marine fish introductions are relatively rare. Of the more than 200 established exotic species in the San Francisco Bay watershed (both freshwater and marine components), only 6 are marine and estuarine fish species (Cohen \& Carlton 1998). Simi- 
larly, of the more than 550 fish introductions reported in the United States, less than 30 were marine fishes introduced to marine environments (Fuller et al. 1999¹). Second, although some fish introductions have been linked to ballast water (Wonham et al. 2000), which is an important pathway for aquatic introductions generally (Carlton 1985, Carlton \& Geller 1993, Ruiz et al. 1997, Wonham et al. 2001), most marine fish introductions have resulted from purposeful releases for fishery development or aquarium releases (Randall 1987). Third, success (i.e. reproduction and dispersal) of many marine fish introductions is often known (Randall 1987, Baltz 1991), whereas success of most other aquatic introductions can be difficult to determine (Ruiz et al. 1997).

Marine fish introductions are thought to have limited effects on ecosystems. It may be that as a result of limited marine fish introductions, and the equivocal effect of introduced fish species on native marine fishes, fisheries and communities, introduced marine fishes have not traditionally been thought of as an important threat (Ruiz et al. 1997). In a review of Hawaiian marine fish introductions, Randall (1987) noted few adverse effects of introduced marine fish species, yet little direct research has investigated potential effects. In addition, there is the specter of ecosystem consequences similar to those experienced in the Great Lakes, where introductions of the round goby Neogobius melanostomus, the European ruffe Gymnocephalus cernuus and the sea lamprey Petromyzon marinus have been implicated, along with overfishing and pollution, in the decline and extinction of several native fish species (Miller et al. 1989, Jude et al. 1995).

This paper documents the introduction and probable establishment of the IndoPacific lionfish Pterois volitans along the East Coast of North America. This represents the first, apparently successful introduction, of a marine fish from the western Pacific to Atlantic coastal waters of the United States. The establishment of lionfish is of particular importance due to its venomous spines, style of predation and lack of known predators. Further, the introduction of lionfish along the southeastern United States coast is of concern because a number of species at a similar

\footnotetext{
${ }^{1}$ Available at http://nas.er.usgs.gov/fishes/
}

trophic level are overfished and the overall fish fauna is already changing.

\section{METHODS, RESULTS AND DISCUSSION \\ Pterois volitans along the Atlantic coast of North America}

Nineteen substantiated observations and 1 specimen collection have been made of the western Pacific lion-

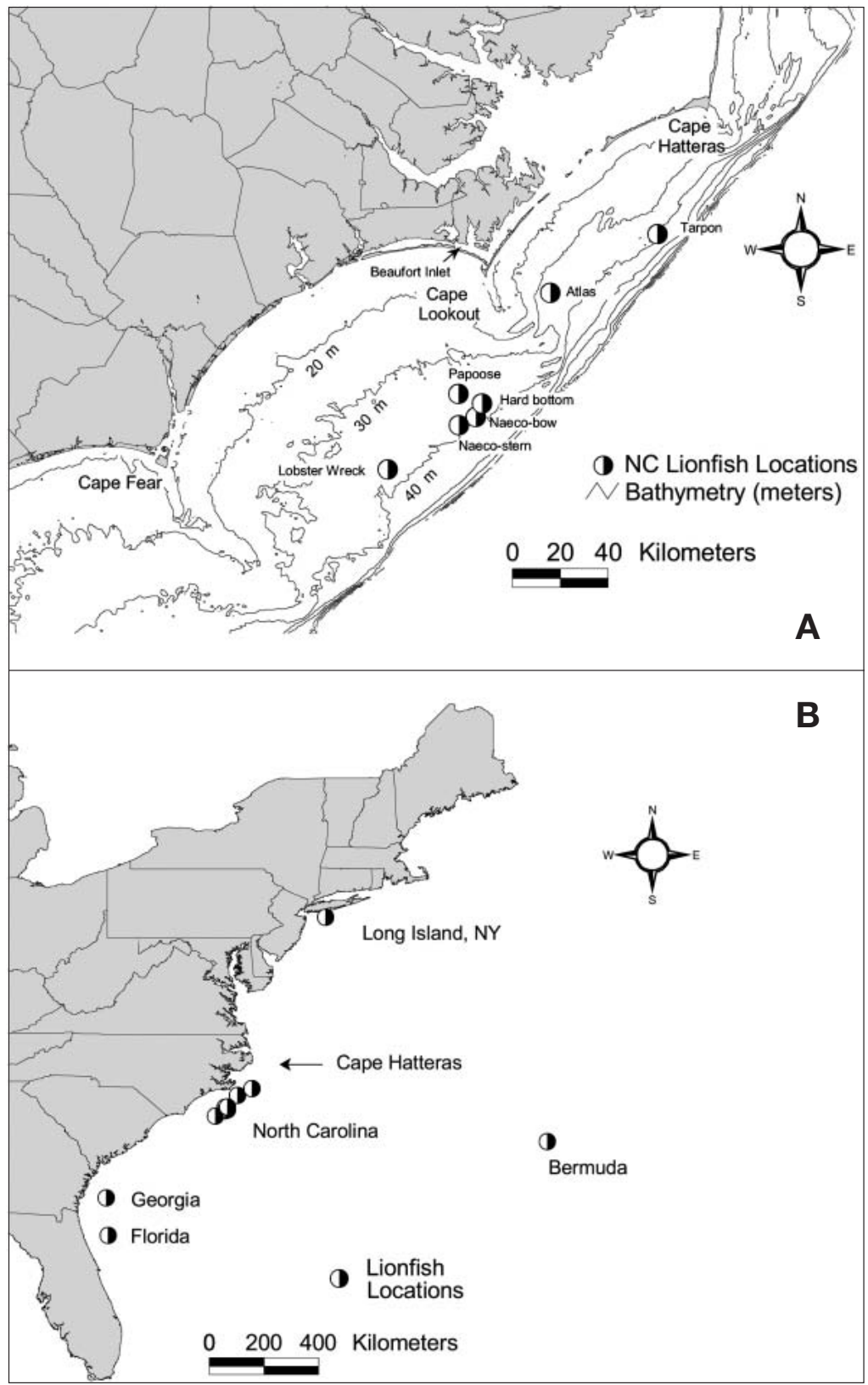

Fig. 1. Pterois volitans. (A) Lionfish sightings along North Carolina coast and (B) in the western Atlantic 
fish Pterois volitans at 8 different locations (Fig. 1A) on the North Carolina continental shelf over the period of $1 \mathrm{yr}$ (Table 1). There have been other reports of lionfish in this area but only observations substantiated with photographs, video or specimen collection are included here. Multiple lionfish were observed on 2 occasions (Table 1). All fish observed off North Carolina were adults (Fig. 2A), and the specimen collected was female.

An adult male lionfish was collected (Fig. 2B) and 2 others observed off the Georgia coast during the summer of 2001 (Table 1). The Georgia site was approximately $500 \mathrm{~km}$ southwest of the North Carolina sites (Fig. 1B). There have been other sightings by SCUBA divers off the coast of Georgia but again, only observations supported by photographs, video or specimen collection are presented.

An adult lionfish (FSBC 19395, FWC-Florida Marine Research Institute) was also collected off the coast of St. Augustine, Florida (Fig. 1B). Multiple lionfish were also observed when the specimen was collected (Table 1).

Two juvenile lionfish (Fig. 2C) were collected on wood pilings along the south coast of Long Island, New York (Table 1) during summer 2001. There are other reports of lionfish sightings along the south coast of Long Island, but only substantiated observations are presented. The Long Island location is approximately $800 \mathrm{~km}$ north-northeast of the North Carolina locations.

In April 2001, a lionfish was entered at the Agricultural Exhibition in Bermuda as part of an aquarium exhibit. The lionfish (BAMZ 2001.198.001, Bermuda Natural History Museum) was collected as a juvenile from a tide pool at Devonshire Bay, south shore of Bermuda, in the late summer of 2000 and maintained in a private aquarium until April 2001 (W. Sterrer pers. comm.). In October 2001, several divers reported another lionfish sighting along the South Shore of Bermuda and photographs were taken (Table 1).

All lionfish specimens collected were positively identified as Pterois volitans. Identification is relatively straightforward. The subfamily Pteroinae (Pisces: Scorpaenidae) contains 5 genera, distinguishable based on presence/absence of unbranched pectoral rays, relative length of dorsal spines to dorsal rays and presence/absence of a tentacle from the lachrymal bone (Eschmeyer 1986). The genus Pterois contains 8 valid species (Eschmeyer 1998) that can be differentiated using meristics, coloration and scale type (Eschmeyer 1986, Schultz 1986). Within Pterois there are 2 allopatric sibling species, $P$. volitans and $P$. miles, that can be separated by dorsal and anal fin ray counts, relative length of the pectoral fin and relative size of the dorsal

Table 1. Pterois volitans. Observations in the western Atlantic Ocean. Meristics and total length (TL) are included if they could be determined. The number in parentheses in the number observed column is the number of lionfish collected

\begin{tabular}{|c|c|c|c|c|c|c|c|c|c|}
\hline Location & Site name & $\begin{array}{l}\text { Depth } \\
(\mathrm{m})\end{array}$ & Date & $\begin{array}{l}\text { Number } \\
\text { observed }\end{array}$ & $\begin{array}{c}\text { Estimated } \\
\text { size }(\mathrm{TL} \mathrm{cm})\end{array}$ & $\begin{array}{l}\text { Dorsal } \\
\text { rays }\end{array}$ & $\begin{array}{l}\text { Anal } \\
\text { rays }\end{array}$ & Observer & Evidence \\
\hline North Carolina & Naeco-Stern & 42 & 10 Aug 2000 & 1 & & & & Renate Eichinger & Photos \\
\hline North Carolina & Tarpon & 43 & Fall 2000 & 1 & & & & John Pieno & Photos \\
\hline North Carolina & Papoose & 39 & 17 Jun 2001 & 1 & & & & Jeff Kuehn & Photos \\
\hline North Carolina & Hard-bottom Site 1 & 40 & 19 Jun 2001 & 4 & & & & Jim Smith & Video \\
\hline North Carolina & Naeco-Bow & 42 & 25 Jun 2001 & 1 & & & & Bobby Edwards & Video \\
\hline North Carolina & Naeco-Stern & 42 & 9 Aug 2001 & 2 & & & & Jennifer Roy & Video \\
\hline North Carolina & Atlas & 39 & 16 Aug 2001 & 1 & 12 & 11 & 7 & $\begin{array}{l}\text { Paula Whitfield } \\
\text { Cindy Burnham }\end{array}$ & $\begin{array}{l}\text { Video } \\
\text { Video }\end{array}$ \\
\hline North Carolina & Naeco-Bow & 42 & 18 Aug 2001 & 1 & 10 & 11 & 7 & Paula Whitfield & Video \\
\hline North Carolina & Atlas & 39 & 31 Aug 2001 & 1 & 12 & & & Paula Whitfield & Video \\
\hline North Carolina & Hard-bottom Site 2 & 40 & 4 Sep 2001 & $5(1)$ & & 11 & 7 & $\begin{array}{l}\text { John Wisniewski } \\
\text { Ryan Tenant } \\
\text { Mike Gerken } \\
\text { George Purifoy } \\
\text { Robert Purifoy }\end{array}$ & $\begin{array}{l}\text { Collection } \\
\text { Observer } \\
\text { Observer } \\
\text { Photos } \\
\text { Observer }\end{array}$ \\
\hline North Carolina & Lobster Wreck & 39 & 28 Sep 2001 & 1 & & & & Bob Decker & Photos \\
\hline Georgia & 40 mile bottom & 38 & 17 Aug 2001 & $3(1)$ & 17.6 & 11 & 7 & Bob Phillips & Collection \\
\hline Long Island & Fire Island Inlet & 1 & 11 Sep 2001 & $1(1)$ & 2.5 & 11 & 7 & Todd Gardner & Collection \\
\hline Long Island & Fire Island Inlet & 1 & 23 Sep 2001 & $1(1)$ & & 11 & 7 & Todd Gardner & Collection \\
\hline Bermuda & Devonshire Bay & $<1$ & Fall 2000 & $1(1)$ & 6.2 & & & Horace Landy & Collection \\
\hline Bermuda & Devonshire Bay & & Fall 2001 & 1 & & & & Ian Murdoch & Photos \\
\hline Florida & Offshore St. Augustine & e 38 & Jan 2002 & $6(1)$ & 18.4 & & & David Hagan & Collection/obs \\
\hline
\end{tabular}




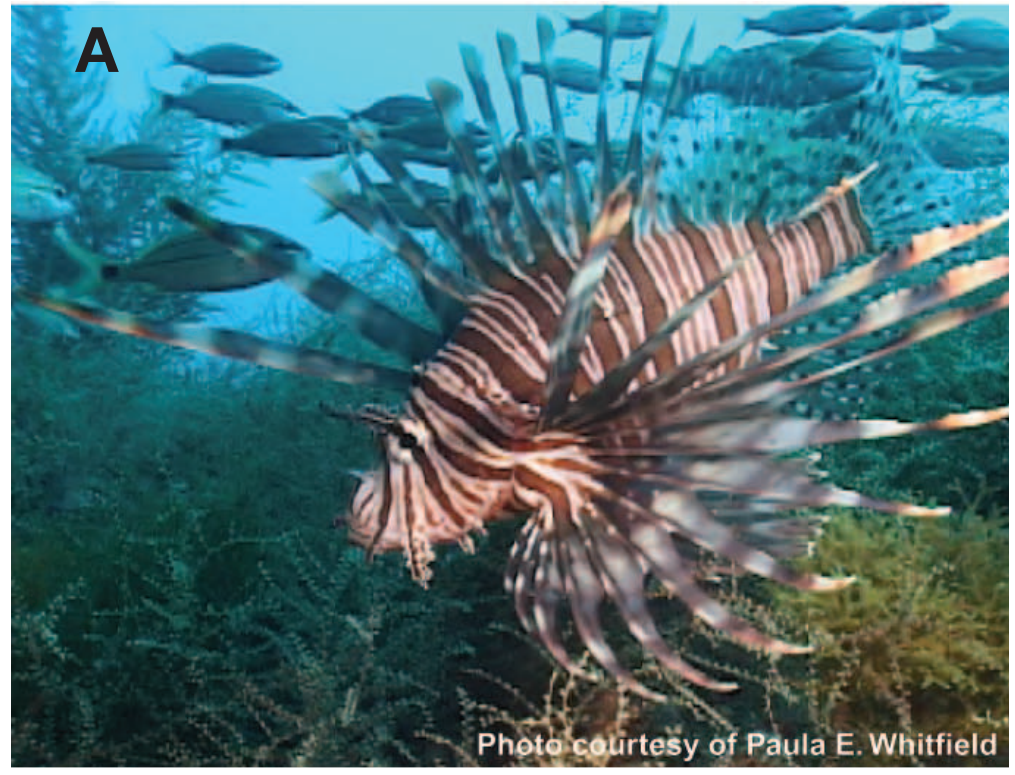

B

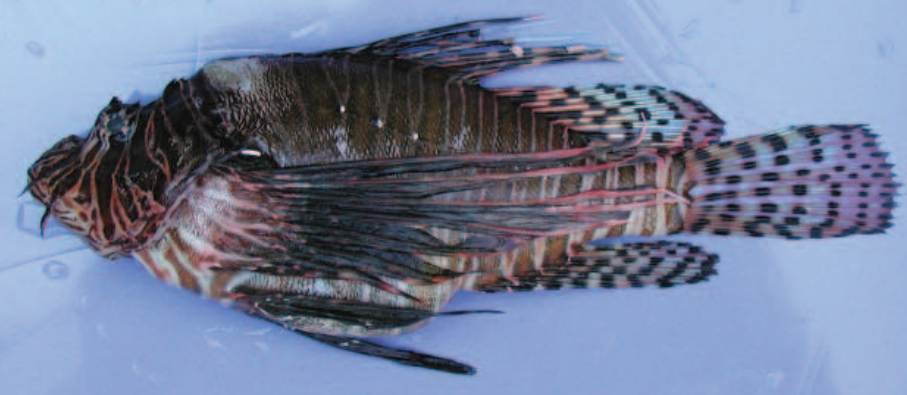

Photo courtesy of Stephen P. Vives

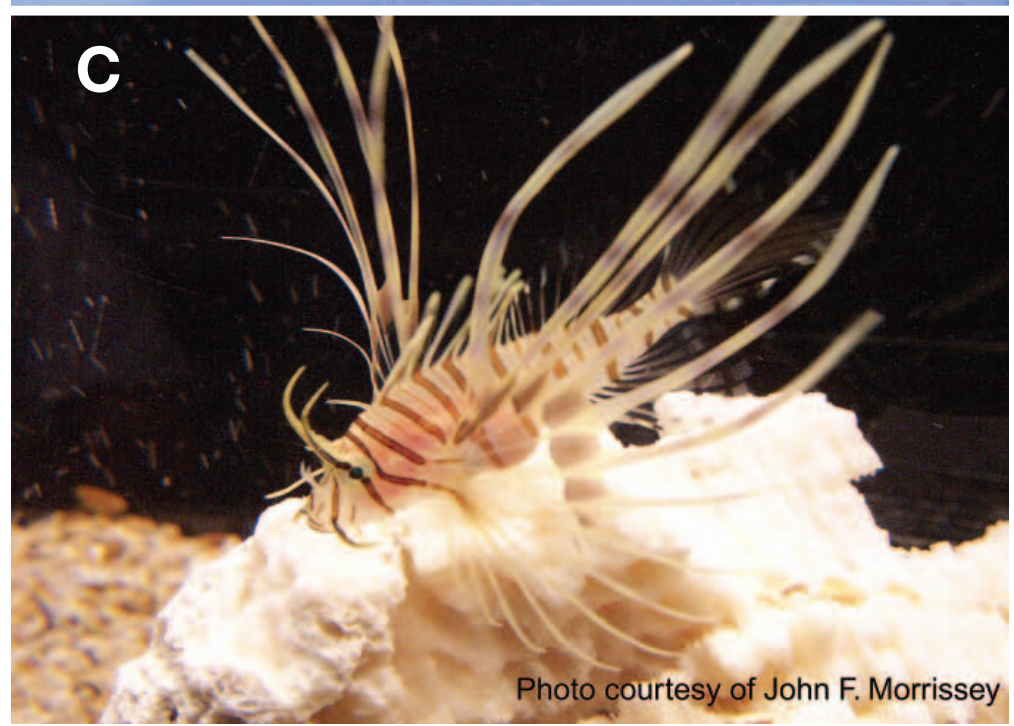

Fig. 2. Pterois volitans. (A) Image of a lionfish from a video taken at the Naeco-bow off of North Carolina. Tomtate Haemulon aurolineatum are in the background. (B) Image of lionfish specimen collected off the Georgia Coast. (C) Image of a juvenile lionfish collected alive off Long Island, New York

fin spots (Schultz 1986). The 5 specimens collected (1 adult female, NC; 1 adult male, GA, 2 juveniles, NY; 1 adult FL) were positively identified as $P$. volitans based on spot size (adults) and meristics (both adults and juveniles): dorsal XIII, 11; anal III, 7; pectoral 14. In addition, 2 fish videotaped were positively identified as $P$. volitans by fin spine/ray counts. All other lionfish photographed and videotaped were assumed to be $P$. volitans, but some could have been $P$. miles (Table 1).

The native range of Pterois volitans extends from southern Japan, south to Lord Howe Island off the east coast of Australia, throughout Indonesia, Micronesia and French Polynesia (Schultz 1986). P. miles replaces $P$. volitans west of Sumatra, throughout the Indian Ocean and north to the Red Sea (Schultz 1986). Both species associate with rock and coral substrate from the surface to $50 \mathrm{~m}$, and many records are from harbor areas (Schultz 1986). Both species have venomous dorsal, anal and pelvic spines and are popular in the aquarium trade (Thresher 1984). The presence of $P$. volitans along the Atlantic coast of North America represents introductions from the western 291 Pacific to the western North Atlantic.

\section{Potential survival of Pterois volitans along the southeastern United States}

The number and spatial distribution of observations suggest that adult Pterois volitans are surviving along the southeastern United States coast. Adult $P$. volitans were observed at 8 sites off of North Carolina, twice during 2000 and multiple times during 2001. Adults were also observed off the coast of Georgia in 2001 and Florida during 2002. The spatial extent and multiple observations of adults suggest that $P$. volitans is distributed over 
a large latitudinal portion of the southeastern United States continental shelf.

Temperature is likely an important factor affecting survival, reproduction and dispersal of Pterois volitans along the Atlantic coast of North America (Longhurst 1998). Two oceanographic and zoogeographic regimes are defined along the east coast of the United States. The southeastern United States continental shelf (Cape Hatteras to southern Florida) contains relatively saline (34 to 36 salinity) and warm (12 to $16^{\circ} \mathrm{C}$ winter minimum) water and a warm-temperate fish fauna (Briggs 1974, Stegmann \& Yoder 1996). The northeastern United States continental shelf (Cape Hatteras to Gulf of Maine) is characterized by slightly fresher (30 to 33 salinity) and colder (5 to $10^{\circ} \mathrm{C}$ winter minimum) water and a cold-temperate fish fauna (Briggs 1974, Mountain \& Holzwarth 1989). Temperature at sites where lionfish were observed on the North Carolina shelf ranged between 14 and $28^{\circ} \mathrm{C}$, but cold periods $\left(<15^{\circ} \mathrm{C}\right)$ lasted only for a few days (Fig. 3A). These winter temperatures are somewhat lower than winter temperatures off Lord Howe Island, the reported southern limit of $P$. volitans in the southern hemisphere (Fig. 3B). Observation of lionfish at many sites over $2 \mathrm{yr}$ suggests that individuals have survived winter temperatures along the southeastern United States coast.

Winter water temperatures on the northeastern continental shelf are likely too cold to permit overwintering by lionfish. Juvenile stages of a number of tropical and warm-temperate species occur along the northeastern coast during summer (Smith 1899, Able \& Fahay 1998) and these fish either perish (McBride \& Able 1998) or successfully return to more southern winter habitats (Kendall \& Walford 1979). Given the sedentary nature of lionfish (Fishelson 1975), it is likely that juvenile lionfish perish when water temperatures cool below the critical thermal minimum.

Water temperature in Bermuda will likely allow survival of lionfish. Bermuda's fish fauna is subtropical/ tropical (Smith-Vaniz et al. 1999) and the subtropical shorefish fauna is more diverse than off North Carolina and Georgia. Thus, if lionfish can survive off the southeastern United States, they certainly can survive off Bermuda.

The occurrence of juveniles strongly suggests that introduced lionfish are reproducing in the western Atlantic Ocean. Also, observation of multiple individuals off North Carolina, Georgia and Florida (Table 1) suggests reproducing populations; Fishelson (1975) reported that Pterois volitans (= P. miles [Schultz 1986]) is solitary and observed in groups of 3 to 8 only during the initial stages of courtship. Although both sexes and juveniles have been collected, mating has not been observed.

Spawning along the southeastern United States continental shelf likely supplied juvenile lionfish to Long
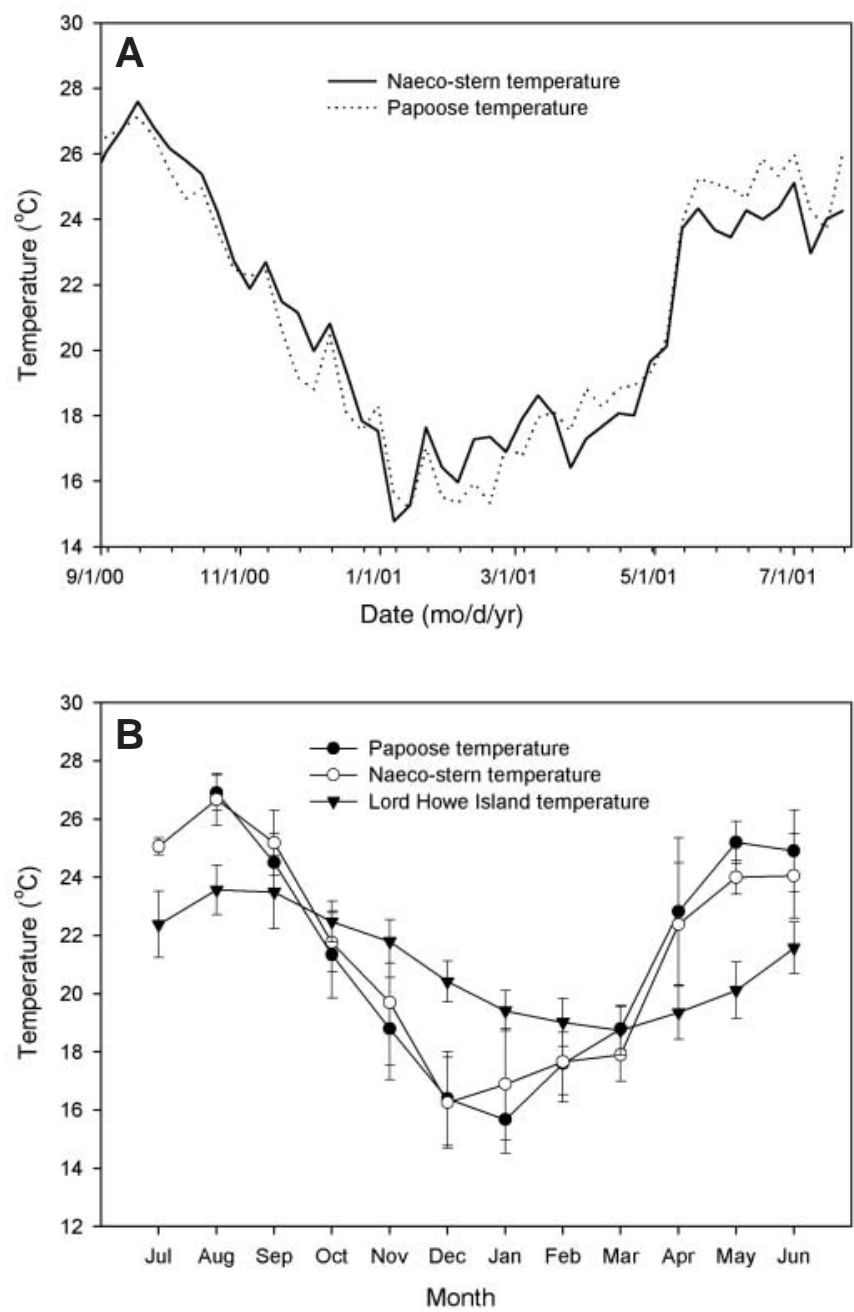

Fig. 3. (A) Mean weekly bottom water temperatures during the winter 2000/2001 at the Naeco-stern and Papoose off of North Carolina. (B) Mean monthly bottom water temperatures and standard deviation for the Naeco-stern, Papoose and Lord Howe Island near the poleward extent of lionfish Pterois volitans in its native range (Lord Howe Island coastal station data 1976-1987; CSIRO Division of Marine Research, Hobart)

Island and Bermuda. Larval transport pathways from the southeastern shelf to the northeastern shelf and Bermuda have been described (Hare \& Cowen 1991, 1996, Cowen et al. 1993, Schultz \& Cowen 1994). Pterois sp. lays eggs in an egg mass, which is pelagic (Breder \& Rosen 1966, Fishelson 1975). Larval duration of lionfish probably ranges between 25 and $40 \mathrm{~d}$; settlement occurs at 10 to $12 \mathrm{~mm}$ (for P. miles, Fishelson 1975) and the typical growth rate for larval scorpaenids is $0.3 \mathrm{~mm} \mathrm{~d}^{-1}$ (Laidig \& Sakuma 1998). This estimated larval duration is well within the range of transport times of other southeastern shelf species expatriated to coastal regions of the northeastern shelf (Hare \& Cowen 1991, 1996) and Bermuda (Schultz \& Cowen 1994). 
In summary, lionfish are likely established along the southeastern United States continental shelf. Reproduction is supplying juveniles to the southeastern and northeastern continental shelves and Bermuda. Population survival is possible off Bermuda but not likely on the shelf north of Cape Hatteras due to cold winter temperatures.

\section{Method of introduction}

A variety of pathways has been described for biological invasions of marine fish species: natural range extensions, deliberate introductions to improve fisheries, movement of fishes through canals, transport in ballast water and unintentional or intentional aquarium or aquaculture releases (see also Baltz 1991, Courtenay 1993). Because there are vast distances and several biogeographic provinces between the native range of Pterois volitans and observations reported here (Briggs 1974), natural dispersal or movement through canals is unlikely. Further, lionfish would not be released for fishery purposes. Thus, ballast water or aquarium release are the 2 most likely introduction possibilities.

Ballast water has lead to introductions of approximately 35 fish species worldwide (Wonham et al. 2000). Most successful introductions are of species in 2 families: Gobiidae and Blennidae (Wonham et al. 2000). There are no reports of successful introductions of scorpaenids resulting from ballast water transport however, 2 individual scorpaenids have been found in ballast water (Wonham et al. 2000). Additionally, lionfish are reported from several harbor areas (Schultz 1986) making an introduction via ballast water possible.

Nevertheless, accidental or intentional release from aquaria is the most likely mechanism of introduction. Pterois volitans is a popular aquarium fish (Thresher 1984) and an accidental release of lionfish was made from an aquarium into Biscayne Bay, Florida in 1992 (Courtenay 1995). Additionally, lionfish specimens collected off the coast of North Carolina, Georgia and Florida appear to be typical of individuals from the central portion of the native range that includes the Philippines and Indonesia (W. Eschmeyer pers. comm.); $85 \%$ of marine aquarium fishes exported to the United States come from the Philippines and Indonesia (Baquero 1999).

\section{Ecosystem effects}

Introduced species can have deleterious (Taylor et al. 1984, Carlton et al. 1990, Nichols et al. 1990, Carlton \& Geller 1993) or minimal effects (Randall 1987) on invaded ecosystems. Pterois volitans feeds on a wide variety of smaller fishes, shrimps and crabs (Fishelson
1975, Sano et al. 1984). All of these prey items are abundant on southeastern United States reefs and wrecks (Wenner et al. 1983). The style of lionfish predation is a slight modification of the typical ambush predators that are common on southeastern reefs and wrecks (red grouper, frogfish, scorpion fish). Lionfish use their outstretched pectoral fins to slowly pursue and corner their prey (Allen \& Eschmeyer 1973, authors' obs.). The lack of experience of prey species with this behavior may increase predation efficiency of lionfish on the southeastern United States. However, without knowledge of diet, dietary preferences and foraging requirements, the impact of lionfish on prey populations and potential competitors for food cannot be evaluated.

Similarly, interactions with potential lionfish predators are also unknown. Few predators of lionfish have been reported within the native range (Bernadsky \& Goulet 1991). Moreover, predators along the southeastern United States have no experience with venomous spines of the lionfish (Ray \& Coates 1958, Halstead 1967).

The southeastern United States reef ecosystem is already undergoing change. Many important reef fish predators are overfished (Huntsman et al. 1999). Simultaneously, the reef fish fauna of the North Carolina shelf is becoming more tropical (Parker \& Dixon 1998) suggesting ecosystem changes that may be favorable to dispersal of lionfish from more tropical populations. These larger scale ecosystem changes make predicting effects of lionfish on southeastern reef ecosystems even more difficult.

At this time, negative effects on the ecosystem are unlikely as the number of lionfish observed is relatively few, but future effects on tropical and subtropical reef communities in the western central Atlantic may occur if reproduction and dispersal of this species results in population growth.

\section{Future work}

Documenting the spatial extent of the introduction and estimating the number of extant individuals are important goals for future research. Efforts should concentrate on reefs and wrecks on the southeastern United States shelf that are $<50$ and $>30 \mathrm{~m}$, based on maximum depth observed in the native range and the depth of individuals observed off the coast of North Carolina (Fig. 4). Efforts to find lionfish juveniles along the east coast of the United States and Bermuda should also continue. Additionally, bottom water temperature should be measured over a large spatial extent during the winter of 2001/2002 and beyond. Temperature data coupled with information on reef and wreck locations 


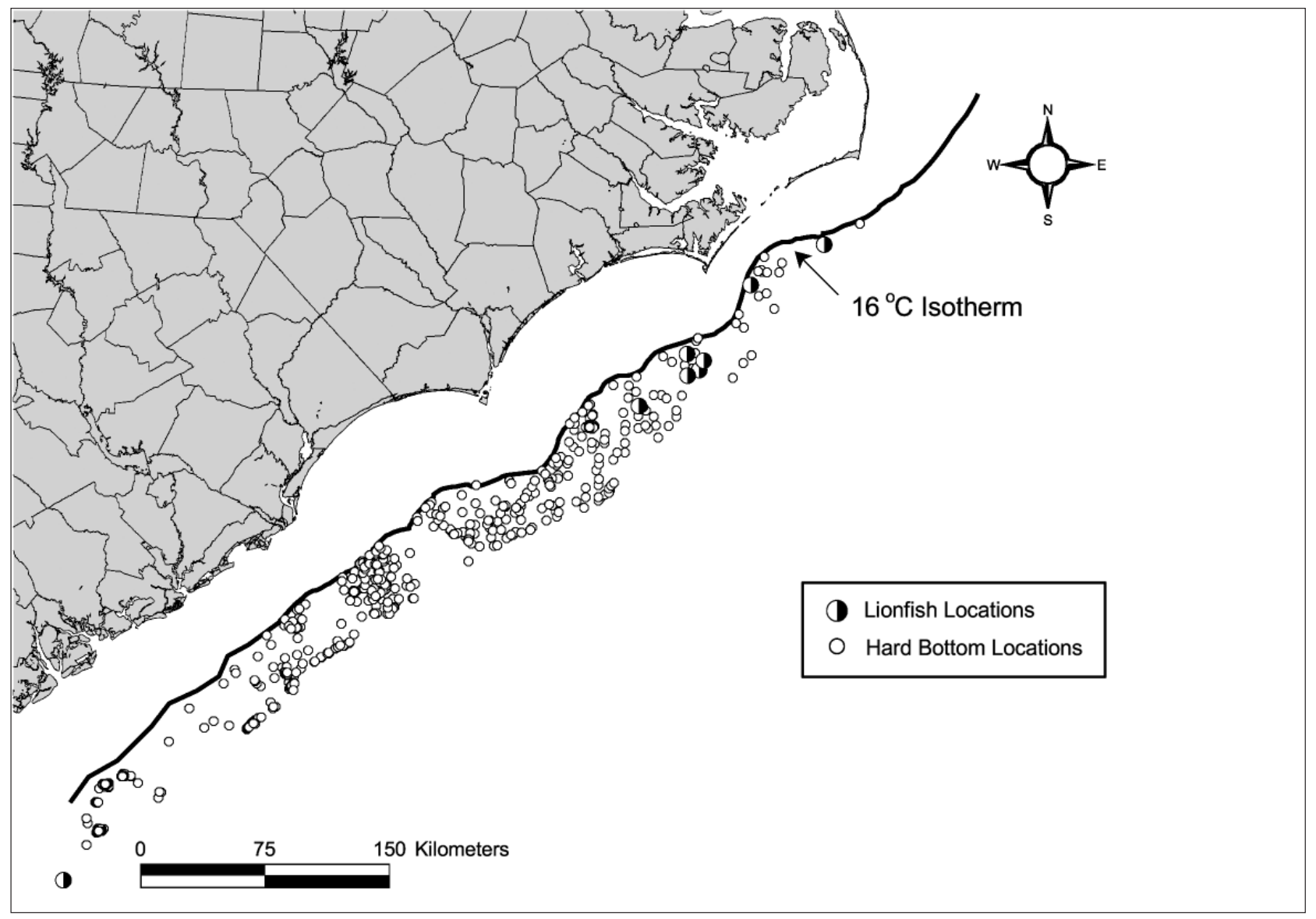

Fig. 4. Best estimate of potential habitat distribution of lionfish Pterois volitans along the southeastern continental shelf. Offshore limit is the $50 \mathrm{~m}$ isobath (Schultz 1986). The $16^{\circ} \mathrm{C}$ isotherm represents a likely inshore limit. The $16^{\circ} \mathrm{C}$ isotherm was taken from a $5 \mathrm{yr}$ average of February sea surface temperature images (see Stegmann \& Yoder 1996); temperature is generally vertically homogenous on the North Carolina shelf during winter and thus surface temperature estimates provide a reasonable measure of bottom temperatures

will refine our understanding of potential habitat distribution of Pterois volitans. Experiments to determine temperature tolerance of lionfish will further define potential range distribution along the southeastern shelf. Genetic studies similar to those of Planes \& Lecaillon (1998) can provide information regarding effective population size and genetic variability of the introduced population. Additionally, genetic studies may be able to identify the source region of the native range which may elucidate the mechanism of introduction (Hauser et al. 1998). Collection of larger lionfish specimens for histological evaluation of their reproductive state will further our knowledge concerning reproduction and potential dispersal. Finally, modeling and/or drifter studies could be undertaken to estimate dispersal of lionfish from observed locations to better predict areas that may receive recruits (Hare et al. 1999).
Acknowledgements. We thank Renate Eichinger and Captain Bobby Edwards for all their time and effort; without their excellent vision, photographs and video, this manuscript would not have been possible. We are also indebted to Cindy Burnham, Dr. Jim Smith, Paul Swenson, Jeff Kuehn, Jennifer Roy, John Morrissey, Bill Mansfield, John Wisniewski, Bill Mansfield, John Pieno and Bob Decker for supplying additional photography and video evidence of the North Carolina specimens. We are grateful to members of the local and not so local dive community for their help and encouragement: Captain George Purifoy, Mike DeCamp, Captain Bobby Cox, Captain Alan Endres, Roy Cowan, Captain Ryan Tenant, Mike Gerken Captain Leroy Craytor, Debby Boyce and Captain Robert Purifoy. We also thank Brian Degan, Gary Fisher, Bob Dixon, Ken Brennan, Mike Burton, Gordon Thayer, Jeff Govoni, Pete Parker and Jim Francisconi. The manuscript was greatly improved by W. Judson Kenworthy, Chuck Manooch, Patti Marraro, Jim Williams, James T. Carlton and 2 anonymous reviewers. We thank William Eschmeyer for identification of the North Carolina specimen, Bob Phillips for collection of the Georgia specimen, John Wisniewski for collection 
of the North Carolina specimen and Captain David Hagan for collection of the Florida specimen. Special thanks are due to Lisa Greene, Judie Clee, and Wolfgang E. Sterrer for information provided on the discovery of lionfish in Bermuda, and Bill Smith-Vaniz for alerting us to this introduction. We thank Ian Murdoch for making available his underwater photographs of the second lionfish found at Bermuda and Wolfgang Sterrer for forwarding scans to us. We also thank Ramon RuizCarus, Richard E. Matheson Jr, Mark M. Leiby and Daniel E. Roberts Jr for information pertaining to the Florida specimen.

\section{LITERATURE CITED}

Able KW, Fahay MP (1998) The first year in the life of estuarine fishes in the Middle Atlantic Bight. Rutgers University Press, New York

Allen GR, Eschmeyer WN (1973) Turkeyfishes at Eniwetok. Pac Discovery 26:3-11

Baltz DM (1991) Introduced fishes in marine systems and inland seas. Biol Conserv 56:151-177

Baquero J (1999) Marine ornamentals trade: quality and sustainability for the Pacific Region. South Pacific Forum Secretariat Trade and Investment Division, Suva Fiji

Bernadsky G, Goulet D (1991) A natural predator of the lionfish, Pterois miles. Copeia 1:230-231

Breder CM, DE Rosen (1966) Modes of reproduction in fishes. American Museum of Natural History, New York

Briggs JC (1974) Marine zoogeography. McGraw Hill, New York

Carlton JT (1985) Transoceanic and interoceanic dispersal of coastal marine organisms: the biology of ballast water. Oceanogr Mar Biol Annu Rev 23:313-371

Carlton JT (1989) Man's role in changing the face of the ocean: biological invasions and implications for conservation of near-shore environments. Conserv Biol 3: $265-273$

Carlton JT, Geller JB (1993) Ecological roulette: The global transport of nonindigenous marine organisms. Science 261:78-82

Carlton JT, Thompson JK, Schemel LE, Nichols FH (1990) Remarkable invasion of San Francisco Bay (California, USA) by the Asian clam Potamocorbula amurensis. I. Introduction and dispersal. Mar Ecol Prog Ser 66:81-94

Cohen AN, Carlton JT (1998) Accelerating invasion rate in a highly invaded estuary. Science 279:555-557

Courtenay WR (1993) Biological pollution through fish introductions. In: McKnight BN (ed) Biological pollution: the control and impact of invasive exotic species. Indiana Academy of Science, Indianapolis, p 35-61

Courtenay WR (1995) Marine fish introductions in southeastern Florida. American Fisheries Society Introduced Fish Section Newsletter 1995(14):2-3

Cowen RK, Hare JA, Fahay MP (1993) Beyond hydrography: can physical processes explain larval fish assemblages within the Middle Atlantic Bight? Bull Mar Sci 53:567-587

Eschmeyer WN (1986) Scorpaenidae. In: Smith MM, Heemstra PC (eds) Smiths' sea fishes. Springer-Verlag, Berlin, p 463-478

Eschmeyer WN (1998) Catalog of fishes. California Academy of Sciences, San Francisco

Fishelson L (1975) Ethology and reproduction of pteroid fishes found in the Gulf of Aqaba (Red Sea), especially Dendrochirus brachypterus (Cuvier), (Pteroidae, Teleostei). Pubbl Stn Zool Napoli 39(Suppl 1):635-656

Fuller PL, Nico LG, Williams JD (1999) Nonindigenous fishes introduced into inland waters of the United States. Am Fish Soc Spec Publ 27

Halstead BW (1967) Poisonous and venomous marine animals of the world, Vol 2. US Government Printing Office, Washington DC

Hare JA, Cowen RK (1991) Expatriation of Xyrichtys novacula (Pisces: Labridae) larvae: evidence of rapid cross-slope exchange. J Mar Res 49:801-823

Hare JA, Cowen RK (1996) Transport mechanisms of larval and pelagic juvenile bluefish (Pomatomus saltatrix) from South Atlantic Bight spawning grounds to Middle Atlantic Bight nursery habitats. Limnol Oceanogr 41:1264-1286

Hare JA, Quinlan JA, Werner FE, Blanton BO, Govoni JJ, Forward RB, Settle LR, Hoss DE (1999) Larval transport during winter in the SABRE study area: results of a coupled vertical larval behaviour-three-dimensional circulation model. Fish Oceanogr 8(Suppl 2):57-76

Hauser L, Carvalho GR, Pitcher TJ, Ogutu-Ohwayo R (1998) Genetic affinities of an introduced predator: Nile perch in Lake Victoria, East Africa. Mol Ecol 7:849-857

Huntsman GR, Potts J, Mays RW, Vaughan D (1999) Groupers (Serranidae, Epinephelinae): endangered apex predators of reef communities. Am Fish Soc Symp 23:217-231

Jude DJ, Janssen J, Crawford G (1995) Ecology, distribution, and impact of the newly introduced round and tubenose gobies on the biota of the St Clair and Detroit Rivers. In: Munawar M, Edsall T, Leach J (eds) The Lake Huron ecosystem: ecology, fisheries and management. SPB Academic Publishing, Amsterdam, p 447-460

Kendall AW, Walford LA (1979) Sources and distributions of bluefish, Pomatomus saltatrix, larvae and juveniles off the east coast of the United States. Fish Bull 77:213-227

Laidig TE, Sakuma KM (1998) Description of pelagic larval and juvenile grass rockfish, Sebastes rastrelliger (family Scorpaenidae), with an examination of age and growth. Fish Bull 96:788-796

Longhurst A (1998) Ecological geography of the sea. Academic Press, San Diego

McBride RS, Able KW (1998) Ecology and fate of butterflyfishes, Chaetodon spp., in the temperate, western North Atlantic. Bull Mar Sci 63:401-416

Miller RR, Williams JD, Williams JE (1989) Extinctions of North American fishes during the past century. Fisheries 1989(14):22-38

Mountain DG, Holzwarth TJ (1989) Surface and bottom temperature distribution for the northeast continental shelf. NOAA Tech Memo Region Number:1-39. NMFS-F/NEC 73:1-39

Nichols FH, Thompson JK, Schemel LE (1990) Remarkable invasion of San Francisco Bay (California, USA) by the Asian clam Potamocorbula amurensis. II. Displacement of a former community. Mar Ecol Prog Ser 66:95-101

Parker RO, Dixon RL (1998) Changes in a North Carolina reef fish community after 15 years of intense fishing-global warming implications. Trans Am Fish Soc 127:908-920

Planes S, Lecaillon G (1998) Consequences of the founder effect in the genetic structure of introduced island coral reef fish populations. Biol J Linn Soc 63:537-552

Randall JE (1987) Introductions of marine fishes to the Hawaiian Islands. Bull Mar Sci 41:490-502

Ray C, Coates CW (1958) A case of poisoning by the lion fish, Pterois volitans. Copeia 1958(3):235

Ruiz GM, Carlton JT, Grosholz ED, Hines AH (1997) Global invasions of marine and estuarine habitats by non-indigenous species: mechanisms, extent and consequences. Am Zool 37:621-632

Ruiz GM, Fofnoff PW, Carlton JT, Wonham MJ, Hines AH 
(2000) Invasion of coastal marine communities in North America: apparent patterns, processes, and biases. Annu Rev Ecol Syst 31:481-531

Sano M, Shimizu M, Nose Y (1984) Food habits of teleostean reef fishes in Okinawa Island, Southern Japan. University of Tokyo Press, Tokyo

Schultz ET (1986) Pterois volitans and Pterois miles: two valid species. Copeia 1986(3):686-690

Schultz ET, Cowen RK (1994) The recruitment of coral-reef fishes to Bermuda: local retention or long-distance transport. Mar Ecol Prog Ser 109:15-28

Smith HM (1899) Fish fauna of the Woods Hole region. Science 10:878-881

Smith-Vaniz WF, Collette BB, Luckhurst BE (1999) Fishes of Bermuda: history, zoogeography, annotated checklist, and identification keys. American Society of Ichtyologists and Herpetologists Special Publication Number 4

Stegmann PM, Yoder JA (1996) Variability of sea-surface temperature in the South Atlantic Bight as observed from

Editorial responsibility: Otto Kinne (Editor),

Oldendorf/Luhe, Germany satellite: implications for offshore spawning fishes. Cont Shelf Res 16:843-861

Taylor JN, Courtenay WR, McCann JA (1984) Known impacts of exotic fish in the continental United States. In: Courtenay WR Jr, Stauffer JR Jr (eds) Distribution, biology and management of exotic fishes. John Hopkins University Press, Baltimore, MD, p 322-373

Thresher RE (1984) Reproduction in reef fishes. TFH Publishing, Neptune City, NJ

Wenner EL, Knott DM, Van Dolah RF, Burrell VG (1983) Invertebrate communities associated with hard bottom habitats in the South Atlantic Bight. Estuar Coast Shelf Sci 17:143-158

Wonham MJ, Carlton JT, Ruiz GM, Smith LD (2000) Fish and ships: relating dispersal frequency to success in biological invasions. Mar Biol 136:1111-1121

Wonham MJ, Walton WC, Ruiz GM, Frese AM, Galil BS (2001) Going to the source: role of the invasion pathway in determining potential invaders. Mar Ecol Prog Ser 215:1-12

Submitted: November 28, 2001; Accepted: March 26, 2002 Proofs received from author(s): May 3, 2002 